\title{
A Journey Through Hell: Dante's influence on Art Spiegelman's Maus
}

\author{
Brian Ireland, Penelope James \\ drbireland@gmail.com
}

\begin{abstract}
In The Divine Comedy, Dante Alighieri conceived of the Inferno as a physical landscape which could be mapped and navigated through. In so doing, he helped create the language and imagery which modern-day writers and artists often turn to when describing Hell. It also created a shared reference point for discussion of horrific events such as the Holocaust/ Shoah. For example, in Survival in Auschwitz [Se questo è un uomo], Primo Levi turned to Dante's Inferno to make sense of his experiences in the concentration camps. In this paper we suggest that comic book artist Art Spiegelman utilised the imagery and lexicon of the Inferno to create Maus, a two volume biography of his father Vladek Spiegelman, a former inmate of Auschwitz and Holocaust survivor. Art Spiegelman utilises structural and thematic elements of Inferno to help explain the tortured relationship he had with his parents, especially the effects on him of his mother's suicide, as well as the difficulties of recording history, particularly an event as immense and traumatic as the Holocaust.
\end{abstract}

Key words: Dante; Divine Comedy; Inferno; Spiegelman; Maus; Holocaust; Shoah.

\section{Riassunto}

Nella Divina Commedia, Dante Alighieri concepì l'Inferno come un paesaggio fisico che poteva essere mappato e attraversato. In tal modo, ha contribuito a creare il linguaggio e le immagini a cui gli scrittori e gli artisti odierni si rivolgono spesso quando descrivono l'inferno. Ha anche creato un punto di riferimento condiviso per la discussione di eventi orribili come l'Olocausto / Shoah. Ad esempio, in Survival in Auschwitz [Se questo è un uomo], Primo Levi si è rivolto a Dante's Inferno per dare un senso alle sue esperienze nei campi di concentramento. In questo articolo suggeriamo che l'artista di fumetti Art Spiegelman abbia utilizzato l'immaginario e il lessico dell'Inferno di Dante per creare Maus, una biografia in due volumi del padre Vladek Spiegelman, un ex detenuto di Auschwitz e sopravvissuto all'Olocausto. Art Spiegelman utilizza elementi strutturali e tematici dell' Inferno per aiutare a spiegare il rapporto torturato che aveva con i propri genitori, specialmente gli effetti su di lui del suicidio di sua madre, così come le difficoltà di registrare la storia, in particolare un evento immenso e traumatico come l'Olocausto.

Parole chiave: Dante; Divina Commedia; Inferno; Spiegelman; Maus; Olocausto; Shoah. 
$\mathrm{T}$ he sheer volume of works about the Holocaust is almost overwhelming but amongst the biographies, autobiographies, monographs, essay collections, memorials, movies, documentaries, art and museum exhibitions, Art Spiegelman's Maus stands out as one of the most innovative and groundbreaking. Maus is a two-volume biography of Vladek Spiegelman, a former inmate of Auschwitz and survivor of the Holocaust. First published as a serial in Raw magazine, collected editions were released in I986 and I991. Maus is written and illustrated by Spiegelman's son Art, who also features in the story as both the narrator and as the character "Artie", through which he weaves together the history of his family's experiences during World War Two and specifically at Auschwitz. Spiegelman portrays the characters in Maus as anthropomorphic animals - Jews drawn as mice and the Germans as cats - a metaphor for the relationship between the Nazis and Jews in the I930s and I940s, which is particularly important and relevant given Nazi propaganda comparing the Jews with rats. I'Tapping into Claude Lévi-Strauss's assertion that animals "are good to think with" (Lévi-Strauss 1962: I28), due to the associations we apply to them, Spiegelman's animal characters become poignant and devastating metaphors for the human condition.

Even now, with the breadth of scholarship available on the Nazi Holocaust, it remains an intensely difficult historical phenomenon to get to grips with. At least six million and perhaps as many as twelve million Jews, P.O.Ws (mainly Russian), gypsies, so-called political undesirables, disabled and mentally ill people perished in Nazi concentration or death camps. With reference solely to Auschwitz-Birkenau, historian Max Hastings notes: "The best available statistics show that a total of I.I million Jews arrived at the camp, of whom I00,000 survived; among I40,000 non-Jewish Poles, half survived; of 23,000 gypsies, all but 2,000 perished; all of the I5,000 Soviet POWs died; about half of 25,000 others - mostly political prisoners - were killed" (Hastings 2OII: 486). The sheer scale, methodology and industrial implementation of Nazi plans for mass murder was unprecedented in human history, and left

I. See, for example, Philipp Rupprecht (known as "Fips") cartoons in Der Stürmer (1923-45), which depict Jews as rats; or Fritz Hippler's 1940 film Der Ewige Jude/The Eternal Jew, which cuts from images of people in the Jewish ghettos of Lodz, Warsaw, Cracow and Lublin, to swarming rats. In this extended metaphor, Art depicts Poles as pigs, Americans as mongrel dogs (rather than pedigree, which perhaps suggests an American "melting pot", the French as frogs, English as fish, and the Swedish as reindeer. Spiegelman bases the metaphor on nationalities, aside for Jews, who are mice no matter what their nationality. Perhaps because many Poles collaborated with the Nazis' anti-Jewish pogroms, Spiegelman portrays them as pigs in the book. While the further Spiegelman strays from the cat and mouse metaphor the more strained it becomes, the overall effect of this type of symbolization is subversion of stereotypes in that it requires the reader to look in a new light at a subject about which a lot has already been written. The reader becomes part of the story rather than a spectator. 
commentators struggling to describe these experiences; particularly those with personal or familial histories to tell.

Many commentators turned to the familiar vocabulary of religion, and the juxtaposition of "Hell" and "Auschwitz" began before full details of the Holocaust were evident. For instance, Zofia Kossak-Szczucka published books during and immediately after the war whose titles refer to "Hell" and the "Abyss". ${ }^{2}$ Many other survivors, commentators, and historians have made the connection since then. ${ }^{3}$ Yet in many respects the vocabulary and imagery of the Bible seemed inadequate to fully encapsulate the horrors of Auschwitz, because the Bible does not depict Hell in any meaningful depth. With the exception of references to Hell as a "fiery lake of burning sulphur" (Revelation 2I:8), or a "burning furnace" (Matthew I3:50), the Bible largely refers to it as a place of spiritual desolation and loneliness, far from the warming light of God. Although at one point Jesus speaks of sinners driven into "darkness where there will be wailing and gnashing of teeth" (Matthew 8:12), the Bible's allegorical and literal teachings have long rested on the idea that Hell is simply a place where God is absent.

However, in stark contrast to the Bible's transitory references to Hell, the medieval poet Dante Alighieri - now revered as perhaps the founding father of Western literary culture - painted a vivid, haunting and terrifying image of Hell in his epic poem, Inferno, (Part One of a trilogy of poems which comprise The Divine Comedy). Dante has often been credited as the first to imagine Hell as a physical place, a landscape he visualized as a structure of nine descending concentric circles, each decreasing in size and each dedicated to punishment for a particular sin, with the intensity of torment increasing as the levels descend down to the ice-cold lair of the Devil. Dante's novel conception of Hell as a monstrous physical landscape in Inferno would go on to shape conceptions of Hell for hundreds of years afterwards, particularly in the arts. For example, in the fifteenth century Sandro Botticelli created the first de-

2. These are: W piekle, trans. "In Hell" (1942) and $Z$ otchtani: Wspomnienia $z$ lagru, trans. "From the Abyss: Memories from the Camp" (1946).

3. For some more recent indicative examples, see: Judith Sternberg Newman, In The Hell Of Auschwitz; The Wartime Memoirs Of Judith Sternberg (Pickle Partners Publishing, 2015); Leslie Schwartz, Marc David Bonagura, Surviving the Hell of Auschwitz and Dachau: A Teenage Struggle Toward Freedom from Hatred (Zurich \& Berlin: LIT Verlag, 20I3); Colin Rushton, Spectator in Hell: a British Soldier's Story of Imprisonment in Auschwitz (Summersdale Publishers, 2007); Alfred Wetzler, Escape From Hell: The True Story of the Auschwitz Protocol (Oxford \& New York: Berghahn, 2007 [1964]); Kon Pierkarski, Escaping Hell: The story of a Polish underground officer in Auschwitz and Buchenwald (Toronto: Dundurn, 1996); Josef Gustav Krawczyk, Living in Hell: An Account of Three Years in Auschwitz (Beacon Press, 1976); Vivien Spitz, Doctors from Hell: The Horrific Account of Nazi Experiments on Humans (Sentient Publications, 2005); Rachel Falconer devotes a section of her book Hell in Contemporary Literature: Western Descent Narratives Since 1945 (Edinburgh University Press, 2005) to Holocaust testimony and fiction. That chapter is entitled "Auschwitz as Hell". 
piction of Dante's version of Hell for illustrated versions of Inferno. Botticelli portrayed a physical place, like a huge underground funnel, which acted as a topography of the descending levels of torment. Similarly, Dante's Canto I: The Dark Wood, was depicted in paintings such as "The Three Wild Beasts" by Joseph Anton Koch (I826-28), and in William Blake's "Dante Running From The Three Wild Beasts", I824-27.4

It is evident that both Dante's original seminal poem, and also the myriad works of art it inspired, provided evocative imagery and a rich vocabulary of language for depicting Hell, and there are numerous examples of Holocaust writers who have drawn specifically upon Dante's Inferno to describe the "Hell" of the Holocaust. We know, for example, that the writer Primo Levi, in his memoir Survival in Auschwitz (1959), recalled reciting lines to another inmate from the Inferno's Canto XXVI in an attempt to make sense of the situation they found themselves in. Scholars of Levi's work have differed as to the importance and significance of Levi's use of Inferno. A. V. Subiotto notes, for example, that while Dante provided imagery and wording that helped the author describe conditions in Auschwitz, Levi does not share Dante's "framework of belief"; instead, Levi "seeks only the most telling discourse for immediate physical experiences" (Subiotto 1991: 77). In contrast, Lino Pertile positions Inferno more centrally in Survival in Auschwitz, arguing for example that Dante's portrayal of Ulysses provides Levi with an inspiring, heroic figure who helps Levi make the profound revelation that there is a future for him beyond the camp (Pertile 20I3: 18). Building on this, it is our contention here that the artist and writer Art Spiegelman utilises the imagery and vocabulary of Dante's version of Hell to help tell his father's story in Maus. As Subiotto explains, Dante helped Levi "to devise means of portraying hell on earth" for those who could not otherwise understand the experience (Subiotto I991: 7I).

In some respects, there are obvious dangers in making too much of a comparison between Dante's Inferno and Spiegelman's Maus. Firstly, it is likely that both Levi, Spiegelman and other Holocaust writers are only too aware of the flaw in the analogy of comparing the death camps to Dante's Hell: as Martin Walser stated in Our Auschwitz (1965), Auschwitz was not Hell, the Jews were no more sinners than anyone else, and the Nazis were humans, not demons. Walser argues that such comparisons alienate us from the reality of both the camps and the conditions that created them. Furthermore, one should be

4. In addition, Dante's description of the entrance to Hell in his Inferno was depicted in a sculpture "The Gates of Hell" by Auguste Rodin, I880-1917. Dante's encounter with damned souls on the Styx river is depicted in Gustave Dorés "Dante Meets Filippo Argenti", I86I. Michaelangelo's fresco in the Sistine Chapel, "The Last Judgement", I536-4I, and Dorés "Charon", I86I, each portray Charon, The Ferryman of Souls from Canto III. One final indicative example is Salvadore Dali's "The Forest of Suicides", 1963, which depicts scenes from Canto XIII. 
hesitant to draw too close a comparison between the Inferno and Maus: after all, Dante's intention was to reaffirm his faith whereas Art Spiegelman tells us his father Vladek "lost all faith" as a result of his experiences in Auschwitz (Spiegelman 20II: 20).

Moreover, Dante's Divine Comedy is a work of fiction, whereas, as Lawrence L. Langer notes, Holocaust writing is concerned with the themes of history and memory: Langer remarks that memory "is not neutral" and that "unlike Dante, the pilgrim of the Holocaust must learn to mistrust all guides, whether they lead us towards closure or not" (Langer 1995: 13). While Primo Levi uses Dante as a guide to assert his humanity in the face of Nazi attempts to dehumanize him (Feinstein 2003: 339), Art's concerns with representation and memory lead him to approach the subject in a different way. As Langer astutely observes, memory can be fallible, and historians have to make sense of many accounts of historical events that may be contradictory. In Maus, for example, when Art asks his father about the musicians who were required to play music at the gates of Auschwitz, Vladek disputes the existence of this event (Spiegelman I99I: Ch. 2). As a pilgrim on a journey of understanding with his father, and as a historian recording his father's memory of events, Art has to interpret the lacuna between his father's memory and other recorded historical sources. 5 So this yawning gap between fiction and historical memory is another major difference between the works of Dante and Spiegelman.

Yet in spite of the obvious pitfalls in comparing the two texts, we know that Spiegelman was familiar with the oeuvre of Gustave Dore and therefore, presumably Dorés illustrations of the Inferno. Furthermore, Spiegelman read Primo Levi's memoir Survival in Auschwitz numerous times, and was "blown away by its humanism and generosity of spirit" (Spiegelman 20Ir:45); and Dante's Inferno is a recurring theme in that work. It is telling also that in discussing the difficulties of representing the Holocaust, critic Thomas Doherty noted that Art Spiegelman's task in Maus was to depict "his father's passage through hell" (Doherty 1996: 70). In Maus, Spiegelman explains his struggles to depict his father's experiences, and the burden of depicting the history of the Holocaust: like many others, he imagined souls suffering in Hell, and it is

5. Spiegelman also asserts his father's humanity by portraying Vladek's negative traits as well as his positive. Indeed, Art portrays Vladek mainly as a dislikable character. As the author actually states at one point, Vladek is in many ways representative of the stereotypical miserable old Jew. Even thirty years after the war, he still saves every little bit of food, steals matches from restaurants, hordes all types of useless articles, and will not spend money unless there is no other option. Art laments that if he only had his mother's diaries then he could present a more sensitive leading character (his mother was also a holocaust survivor but she committed suicide in 1969). However, because Vladek is not a particularly likable person his story seems more authentic. And the result of Vladek's unflattering portrayal is that Maus never degenerates into maudlin sentimentality, retaining its gritty realism. 
Dante who has given us the infernal imagery that seems most appropriate to describe the indescribable.

We therefore posit here that there are four key ways in which Spiegelman draws inspiration from Dante's epic poem to help him tell his father's story. The first is the stylistic form which Dante and Spiegelman chose to tell their monumental stories; both authors, in their own ways, rejected the "accepted" form of writing that was stipulated in their respective times, and deliberately chose a form for their work that would reach the widest possible audience. Related to that point, Subiotto notes that Dante and Levi "cast their descriptions in the discourse of the witness bearing testimony" (Subiotto I99I: 74), and Spiegelman follows their example. The second way we suggest that Dante influenced Maus is in Spiegelman's authorial decision to locate himself as both narrator and character in Maus, much like Dante did in Inferno. Thirdly, we consider how Maus mirrors Inferno in the way it explores the complex themes of life, survival and memory through the central narrative of a father-son (or teacher-pupil) relationship; in much the same way as Dante explored the deepest questions of moral life through the paternalistic Dante-Virgil relationship, Maus does the same with the Holocaust through Artie-Vladek encounters. Finally and perhaps most pressingly, we also contend that Spiegelman borrows extensively from Dante's ideas of the physical landscapes and rich imagery from Dante's Hell to visualize the horrors of life at Auschwitz and Dachau. In short, we argue that Spiegelman was clearly influenced by both structural and thematic elements of Inferno, which he utilised to help explain both the tortured relationship he had with his parents, especially the effects on him of his mother's suicide, and the difficulties of recording history, particularly such an immense and traumatic event as the Holocaust.

The first point of comparison between Spiegelman and Dante is that both artists were striving to convey ineffable themes of human history in a form that could reach the widest audience: both artists rejected and reached beyond the "accepted" form of communicating these ideas in their respective times. In Spiegelman's case, he discarded the idea of a Holocaust memoir, or narrative history; in Dante's case, he aimed for a "comedy" rather than a traditional tragedy that was deemed suitable for a man of his class and the themes under discussion. As the critic David H. Higgins has noted, in Dante's time the canons of literary style were ruled by classical theory, which separated the high (or tragic) style, from the middle (or comic), and the low (or elegiac). Higgins observes that as a member of the petty aristocracy, Dante had previously penned his poetry in the high style ("in which lofty thought is expressed in elevated style"), but for The Divine Comedy, Dante deliberately chose the comedic style (Higgins 2008: 20). Higgins argues this was the case because Dante had intended for The Divine Comedy to act as "gospel to convert his re- 
calcitrant age": as Higgins and many other scholars have emphasized, Dante's poem was a bitter lament against the "widespread materialism, religious cynicism and political opportunism" of his age, and a rallying cry against corrupt Papal authority and of "dilatory emperors" who had strayed from what Dante deemed as the sacrosanct mission of the Holy Roman Empire. Dante intended for his "gospel" to serve as a warning for his contemporaries of the punishments-to-come if they stayed on their sinful paths, and also an insight into the "rewards of right living" (Higgins 2008: 2I). Quoting from Dante's letters, Higgins suggests that Dante chose the comic style for his work because it was in the language of the common people (in which Dante noted that, "even women-folk converse"!) (Higgins, 2008: 20). In other words, Dante wanted his modern gospel to be heard by common people, rather than read (as the "word of God" was at the time, by preachers to audiences). In short then, Dante did not want his morality tale to be only for educated elites, he wanted it to be accessible.

Although Spiegelman grappled with a markedly different challenge to Dante, it could be argued that he too shared Dante's passionate desire to find a stylistic form for his work that "cut right across this rigid notion of art" (Higgins 2008: 20). In 195I, the philosopher Theodor Adorno posited that, "to write poetry after Auschwitz is barbaric" (Adorno 1983: 34), meaning that the reality of Auschwitz was essentially unimaginable and any artistic representation threatened to trivialize events and experiences or perhaps even "transmute it into a form from which one can derive aesthetic satisfaction or ... pleasure" (Loman 2006: 556-7). Arguably, Adorno's observation has shaped Holocaust writing ever since. Thomas Doherty remarks that the "approved style" of Holocaust literature is "unadorned understatement", with particular emphasis on historical accuracy (Doherty 1996: 79). Spiegelman's main challenge, therefore, was how to tell his family's history as Holocaust survivors within these boundaries of depiction and representation: ${ }^{6}$ as an experienced and talented artist, sequential art seemed, for him, the best mode of storytelling.

However, sequential art was associated with comic books, and they were associated with children's entertainment: Spiegelman wondered if it was appropriate, therefore, to depict the Holocaust in such a way. As Thomas Doherty notes, the comic book medium "[b]y its very nature ... seems illequipped for the moral seriousness and tonal restraint that have been demanded of Holocaust art" (Doherty 1996: 79). Yet Spiegelman persisted and in the late 1980s, when Maus was first released in collected format, the most

6. There are three main narrative strands: Vladek's story (businessman, soldier, holocaust survivor, American); Artie's story, particularly his relationship with his parents; and the author's concerns about representation, authenticity, and imagining an event in which he was not a participant. 
commonly used term for this type of commercial product was graphic novel. Maus was perhaps the earliest of these to be taken seriously by mainstream literary critics, so much so that it became the first of that genre, in 1992, to win a Pulitzer Prize. This critical breakthrough led to acceptance of other illustrated tales as works of serious literature aimed at adults. ${ }^{7}$ Therefore, both Dante and Spiegelman, in their markedly different ways, cut across the "accepted" forms of art in their respective periods, to tell their stories in a way designed to reach the widest possible audiences. Both works were meant to be visualised: Art's through art and graphic novel; Dante's through being heard. Both aimed to communicate with the masses, not just an educated elite.

Both authors were also tapping into powerful ideas of morality which ruled their respective societies. For example, Artie makes clear that Vladek subscribed to the "American Dream" ethos, the notion that in the United States there is no obstacle to success and that hard work and enterprise will bring success. Time and time again, Art emphasizes that from Vladek's point of view, he survived Auschwitz and Dachau because he could turn his hand to anything, had learned multiple languages, and was willing to "hustle" to get ahead of the pack. Vladek repeatedly taunts Art for not being able to be a handyman like he is. In Vladek's view, that is why he survived (although, as we know, his survival was more likely to be in the timing of his imprisonment at Auschwitz). Dante's narrative is very similar: Virgil and then Beatrice show him that if he stays on the right path, learns from what he sees around him, follows Virgil's advice, works hard at his ethics and living a good life, he will enter Paradise.

The second key point where Maus bears striking resemblances to Dante's Inferno is the way in which Spiegelman establishes himself as a both an author and key character in his story, as "Artie" - in a markedly similar way to Dante's own characterization of himself in Inferno. In the opening scene of Inferno, Dante finds himself "Half way along the road we have to go" in a perilous state; he is lost and "obscured" in a great forest (Canto I). When he soon thereafter encounters the great philosopher Virgil, and asks him why he must undertake this journey through Hell with him, Virgil replies that a "blessed and beautiful" lady in Heaven (who we discover is his first love, Beatrice) had asked him to go to the aid of her friend Dante, who is "in such difficulty" on the desert hillside and "turns back for fear" (Canto II). The implication is clear: Dante, halfway through his life, is lost and surrounded by temptation; he is struggling to work out his future and his place in history. Art, too, was at a similar crossroads in his own life when writing Maus, and represents himself

7. Among these are graphic novels such as Neal Gaiman's Sandman (1989), Frank Miller's The Dark Knight Returns (1986) and 300 (1988), and Alan Moore's Watchmen (1987), Saga of the Swamp Thing (1987), V For Vendetta (1989), and From Hell (1999). 
as such. He depicts himself as grappling to find his place within his family, as struggling to relate to his domineering father, and wrestling with his family's place in the story of Auschwitz and the Holocaust. Art, like Dante, is both inside and outside the story; the reader can therefore identify with the character's trials and tribulations on a personal and emotional level. By retaining simultaneously their role of narrators, they take us with them on their pilgrimage through their journeys of understanding.

Moreover, in mirroring Dante's dual roles in Inferno - as author/narrator and as core character - Spiegelman, much like Dante, makes clear he is aware of being both an active agent in creating, and also a recipient of the history/ story he is writing. While for the most part in Inferno, Dante casts himself as an observer - observing each level of Hell, learning from Virgil and recording his encounters with the sinners he meets - but he is also keen to show his audience that he is acutely aware of his role as an author, too. For example, in Canto IV, Dante enters the "blind world" of the First Circle of Hell, which is Virgil's realm, and where the least sinful sinners dwell (those who have "committed no sin" but have the "deficiencies" of being un-Baptised or having lived before the Christian era). When Dante beholds Virgil's companions - the great writers, Homer, Horace, Ovid and Lucan - Dante is happy that "They turned towards me with signs of recognition", and is even more thrilled when "they did me a still greater honour;/They took me as a member of their company;/ So that I was sixth among those great intellects". In this masterstroke, Dante lets readers know that as well as casting himself in his submissive role as Virgil's pupil and as hapless pilgrim, he is equally aware that he is an esteemed author, destined for greatness. The tension between the protagonist Dante (where he casts himself as a child-like pupil of Virgil, observing, taking lessons and being tested for his goodness) and the author Dante (confident of his own greatness in posterity as a great poet) subtly suggests to the reader that Dante is aware that in telling this story - which as we know he intended as a modern gospel for his times - he takes on a huge responsibility to make his Divine Comedy worthy of his bestowed status as one of the six greatest poets of all time. In other words, as his mission and subject matter in his Divine Comedy are so very important, he is letting the reader know he is aware of how vital it is that he tells it well.

Spiegelman draws upon the Dante-esque device of using a dual identity as both core character and author, albeit for markedly different reasons. In presenting himself as both author of this story and a central character inside it, like Dante, he is showing his readers that he is mindful of both his own role as a "child" pilgrim in the story he is constructing (that is, learning from his father about his family's horrific experiences of Auschwitz), while also grappling with the tremendous responsibility he also feels as the author 
of Maus. For instance, there is some suggestion that Spiegelman struggled with Adorno's position: in Maus II: A Survivor's Tale: And Here My Troubles Began, Spiegelman entitles Chapter One "Mauschwitz", which seems deliberately provocative in that the pun might undermine the seriousness of the real-life story being told. Critic Erin McGlothlin states, "With the title 'Mauschwitz,' the text pushes to its breaking point the trope of the cartoon animal and its tendency to erase difference in the pursuit of metaphorical conformity, to the point that it threatens to displace history and transform it into a commodity of mass culture and cartoon kitsch" (McGlothlin 2003: I86). Perhaps though the title signifies Spiegelman's awareness of Adorno's thoughts and also of the negative criticism Maus I received for supposedly trivializing the Holocaust. For example, the chapter begins by depicting Art debating how he should depict his French girlfriend: should she be a mouse, as she is Jewish, or a frog as she is French? This invites the reader into the author's thinking and decision-making processes, particularly with regard to the cat/mouse metaphor.

Furthermore, in case readers should think the author treats the subject with levity, Spiegelman entitles the next chapter "Auschwitz (Time Flies)", which reminds readers that while "Mauschwitz" exists to serve the story, Auschwitz is the story. This is reinforced by a particularly harrowing scene in this chapter wherein Spiegelman the author depicts himself as Artie the character, in the process of writing the book in his New York apartment. He recites the dates of important events at Auschwitz and in both his father's and his own life. He depicts flies buzzing around him while he works, and in the last panel on the page a mound of bodies is depicted in the foreground while the view through his window is of Auschwitz instead of New York. This particular scene exemplifies the author's struggle to justify his decision to tell this grand historical story through the medium of sequential art; and these two chapters epitomize his struggles with representation, and perhaps some guilt about the choices he made.

To return to Adorno's point, in a 1996 cartoon called "Mein Kampf (my struggle)" for New York Times Magazine, Spiegelman said "I still prowl the murky caverns of my memory but now I feel like there's a 5,000 pound mouse breathing down my neck!" (Spiegelman 20II: I2-I3). Machteld Harmsen contends that this cartoon is evidence that Spiegelman's "guilt has not been resolved with the publication of Maus. On the contrary, the fact that it was such a critical and commercial success has confirmed him in his opinion that he has become a major artist and money-maker at the cost of millions of innocent people who died in the Holocaust" (Harmsen 20I0: 84). In short, by positioning himself in Maus as both author and character, he can then broach directly with his readers and critics his discomfort, guilt and awareness of the 
pitfalls of Maus' success. This duality allows Spiegelman to explore some of the challenges of living with the commercial success of Maus and the sense of urgent moral anxiety that he faces in profiting financially from his father's horrific story. (In contrast, Pertile argues that Dante had no similar reservations: "Dante does not feel ... there is anything problematic about making literature out of the terrifying reality of pain. On the contrary, the Divine Comedy justifies and authorizes the imaginary fears that are responsible for the creation and preservation of hell" (Pertile 20I3: II)).

Thirdly, in addition to the similar way in which Dante and Spiegelman cast themselves as both authors and characters within their respective works, Spiegelman also articulates the story of Maus through the narrative anchor of a father-son relationship (Maus is predicated essentially on Vladek telling his son Artie his story of Auschwitz), much as Dante does in Inferno (as Virgil the patriarchal father figure guides Dante through hell). Of course, there are markedly obvious differences: unlike Vladek to Artie, Virgil is not Dante's father, and Dante displays an unwavering, largely unquestioning respect for and obedience to Virgil that Artie does not display for Vladek. Yet there are illuminating points of convergence.

In Inferno, Virgil is a patriarchal figure, and the voice of "reason", guiding Dante through Hell. Dante respects him, is submissive to, and in awe of him - on first hearing that Virgil has come to rescue him, Dante dramatically declares to him "You are my master, and indeed my author" (Canto I) - and at several points Virgil acts out the role of father. In Canto XI, for instance, when Dante and Virgil pause on the edge of Lower Hell, Virgil earnestly addresses Dante as "my Son", and maps out for him the rings of Lower Hell, where the graver sins under the rubric of malice are punished (Canto XI): and at frequent points in the poem, Virgil acts alternately as protector, teacher and role model. Yet there are also power tussles between them: while Virgil looks on Dante with love when he expresses the correct moral responses to the sinners - Dante notes with pride that Virgil is particularly proud of him during his fiery exchange with the miserable Pope Nicholas III in Canto XIX, where Dante laments avarice which "brings much grief to the world, / Oppressing the good and helping on the wicked" (Canto XIX) - but Virgil is also irritated by Dante's curiosity, or angered when he seems to forget his moral teachings, or when he asks the obvious. This is particularly poignant in Virgil's outburst in Canto XI, when after carefully explaining the plan of the three rings of the Seventh Circle of Hell (filled with those "accursed spirits" guilty of sins of violence), Dante queries why the other sinners they have already met do not also dwell in this "glowing city" of Lower Hell (Canto XI). Virgil is angry, both that Dante clearly has not been listening - "Why does your mind wander so/ And so much more than it is accustomed to do?" (Canto XI) - but 
also that Dante seems to have forgotten his basic teachings of Ethics, which separates the sins of "incontinence" (those sins which least offend God, which are punished in the less severe Upper Hell) and those of "malice" (punished with greater severity in Lower Hell) and he indignantly gives Dante a good lecture on lessons he should have remembered. While for the most part it is a relationship based on love and teaching, Dante and Virgil's relationship is also a mixture of paternal love, frustration and wrangling.

Dante and Virgil's relationship share many characteristics of the relationship between Art and Vladek. In one respect, Artie, like Dante, is in awe of Vladek as a father figure: much as Dante respects Virgil and wants to learn from him for his wisdom and philosophy, Art reveres his own father's survival in Auschwitz and is keen to learn from him and record his teachings. Yet they bicker constantly: Art is frequently frustrated by his father's obsessive and neurotic behavior such as counting pills, nails, buttons, and money. At one point of bitter exasperation, he says of Vladek, "In some ways he's just like the racist caricature of the miserly old Jew" (Spiegelman 1986: Ch. 6). Here Art reveals the uncomfortable truth that not all victims might be likeable. Art does not share his father's values, and he cannot understand Vladek's behavior, but of course he does acknowledge that what happened to Vladek helped shape his postwar life. Thus, the father-son dynamic allows Art to explore the idea of the "victim": in Dante's case, Dante (the man) is fallible, prone to laziness, and taking the wrong path. In contrast, Virgil the master/teacher/father, is infallible. In Artie's case, the opposite applies: unlike Virgil, Vladek is more difficult to trust, and is not necessarily a role model or a reliable guide. Moreover, of course, the victims in Inferno are sinners and the underworld exists to punish them; in contrast, in the Holocaust the Nazis were the sinners and their victims innocent. Pertile notes perceptively, "The Lager is a perverse, grotesque parody of Dante's hell in that it employs infernal structures in order to punish the innocent and reward the guilty" (Pertile 2013: I6).

In one part of Maus, Spiegelman portrays himself as Art, speaking to his psychiatrist, and recalls that while he wants to respect his father's story, that: "Mainly I remember arguing with him ... and being told that I couldn't do anything as well as he could" (Spiegelman 1991: Ch. 2). And when he discovers that Vladek destroyed his mother Anja's Auschwitz diaries, Art bitterly, angrily, explodes: "God DAMN you! You MURDERER! How the hell could you do such a thing?" While Vladek initially tries to explain it away, it is clear that Vladek is able quickly to move on, and soon nags Artie to telephone him and visit him more often, as if all is back to normal: yet the last illustration shows Artie, alone, head down and walking away, simply saying "MURDERER" (Spiegelman 1986: Ch. 6). In Inferno, Virgil acted as Dante's escort through Hell, allowing Dante to witness his surroundings, while also 
sheltering and protecting Dante from actually experiencing it. In contrast, while Art was physically unable to experience the Holocaust, it nevertheless left emotional and psychological scars, this despite Vladek's attempts to shelter and protect him from the past, from his mother's depressive episodes, and from her suicidal behaviour.

Finally on this aspect, it is useful to point out here that in some ways Dante's own life story is also reminiscent of what happened to Vladek Spiegelman in real life. We know that after incurring Papal wrath for his decisions as a respected Florence Prior, Dante, was stripped of all his wealth and exiled from his home, with the certainty of death by fire if he were ever to return. In a similar way, Maus documents how Vladek Spiegelman went from being a respected, wealthy businessman in his wife's family hosiery business (which Vladek recalled as being "one of the biggest in Poland") to being stripped of nearly everything as the Nazis tightened the noose on the Polish Jews. Interestingly, in his fictional character, Dante opens his Inferno with himself being lost and obscured by a great forest, implying he has strayed from both the physical and spiritual path. This places him in danger as he encounters three beasts, a lion, a leopard and a she-wolf, representing lust, pride and avarice the three great sins. It is clear at this point that his mortal soul is in jeopardy, and it requires the intervention of his guide, Virgil, a symbol of wisdom, rationality, intelligence and art, to drive the beasts away. A similar dislocation occurs in reality for Vladek Spiegelman: as depicted in Maus I, Vladek describes to Art how he was made to join the Polish Army in 1939. In contrast to their actual interview transcript, which is reprinted in Metamaus (Spiegelman 20II: 238), the scene shifts abruptly from this interview to an image of Vladek the soldier, in a forest on the opposite bank of a river from German forces. Art omits Vladek's testimony about "trainings and preparations", possibly to emphasise Vladek's abrupt transition from civilian to soldier. Danger is evident, as bullets fly past his face and over his head. Like Dante, Vladek becomes acquainted with death when he shoots a German soldier and later, as a prisoner, is made to recover the corpse. From this point onwards, it is clear that both men's lives have changed suddenly, and there is no escape. There is inevitability to their fate: Dante's path is predestined - part of his muse Beatrice's plan to save his soul. For Vladek, all roads seem to lead to Auschwitz. Art depicts this in Maus $I$, with a series of roads drawn in the shape of a swastika. The Nazis surround them and the roads lead only to captivity. In the distance, another road leads to smoke stack, which suggests the path to Auschwitz is inevitable (Spiegelman 1986: Ch. 5).

There are similar clear links between the way Spiegelman establishes the role of his mother Anja (and Vladek's first wife) in Maus, to the way Dante casts the role of Beatrice (his unrequited love) in The Divine Comedy. Beatrice 
is based on a real-life person (Beatrice Portinari) who Dante was infatuated with, even though they met only a few times and there was no romantic relationship. When she died in her mid-2os she seemed to symbolise to Dante a kind of idealised muse that could only exist in the afterlife: Beatrice is the symbol of ultimate purity in Inferno, but only through death. As a character in the poem she is both his guide through Heaven (taking over from Virgil as Dante's guide because the pagan Virgil is not pure enough to enter Heaven), and is also the person responsible for Dante's pilgrimage through Heaven, Purgatory and Hell; it is because she sees that he is lost and on a sinful path that she sets him on his divine journey to guide him back to a righteous path. Virgil describes her as "so blessed and beautiful" (Canto II) and it is her love that saves Dante; the inference is that, because of her loving intervention, she and Dante will regain their platonic, loving relationship for eternity. Like Beatrice, Anja Spiegelman becomes more "perfect" in death: particularly for Vladek, for whom she always represents the ultimate symbol of goodness and love. For instance, when Vladek tells Art how, on arrival at Auschwitz, men and women were physically separated, he emphasises that the bond between Vladek and Anja was unbreakable: "But you understand, NEVER, Anja and I were separated!", he insists (Spiegelman I99I: Ch. I). When Artie questions him, Vladek exclaims: "No! The war put us apart, but always, before and after, we were together." Much like Dante then, in spite of having a new wife - the long-suffering Mala - Anja remained the love of Vladek's life. The closing picture of the two Maus volumes is of Vladek and Anja's joint grave headstone.

Likewise for Art, his mother is a symbol of purity that he can never match, and after her suicide he finds it difficult to live with his grief and shame. This is depicted in the chapter "Time Flies" wherein he is literally infantalised by the celebrity status he has achieved: under a barrage of question, he cries "I want my MOMMY!" Emily Miller Budick calls Maus "a ghost story" (Budick 200I: 379) and the memory of Anja and Beatrice haunts both Art and Dante, just as the horror of the camps continued to haunt Vladek until his death in the United States in $1982 .{ }^{8}$ Yet in both Maus and Inferno, in spite of the central role of Beatrice and Anja, it is only men who can tell stories: of all the spirits Dante meets and speaks to, only one of them is a woman (and she is accused of adultery). In Maus, Vladek has disposed of Anja's diaries so her story is mediated through Vladek; and Mala, Valdek's current partner, is also a survivor of Auschwitz, but neither Art nor Vladek even think to ask for her story.

Yet perhaps the most compelling connections between Dante's Inferno and Spiegelman's Maus are the way in which Dante mapped the structure and purpose of Hell, and the ways in which Spiegelman mirrored this in his own

8. Andrew Loman (2006: 560) claims that the main lesson from Maus is that Vladek "never left the camps and its traumas behind, which instead accompany him as ghosts." 
retelling of Vladek's story. As we know, Dante mapped out the Nine Circles of Hell: the first five circles of Upper Hell punishing those lesser sins of "incontinence", and the next, more horrific, four circles of Lower Hell punishing those of "malice" and "frantic bestiality". Dante depicted this hell as a planned, descending landscape in which each level had a specific function of torment and torture for the sinners condemned according to their crimes. Now, of course we need to emphasise again that unlike Dante's fictional Hell - where for Dante sinners are justly punished for their sins in life - the Nazi death camps had a totally different function: they were deliberately conceived to exterminate an entire race of people, as well many other racial or social groups the Nazis deemed unworthy of life. Yet the point to make is that like Dante's Hell, the camps were deliberately mapped out: they were the end product of a structured plan of punishment and extermination that began with Hitler's Mein $\operatorname{Kampf}$ (1925) and came to fruition at the Wannsee Conference in 1942, wherein Reinhard Heydrich directed Nazi functionaries how to implement the "Final Solution" to the Jewish problem. The Final Solution began with dehumanizing propaganda, such as Nazi films and cartoons portraying Jews as vermin and rats. When the war began, Nazi policy was implemented in two stages: in the initial phase, a concerted effort was made to round up and document the Jewish population. Jewish people were herded into ghettos in $\mathrm{Na}$ zi-occupied countries wherein the old and sick were separated and sent west to their deaths in concentration camps. During this time, families were broken apart; for example, Vladek sent his son Richieu to live with his aunt Tosha in the town of Zawiercie but when it became clear that Jews were to be rounded up there, Tosha poisoned herself and Richieu to avoid being sent to Auschwitz.

Between 1942-1943, most of the Jewish inhabitants of Nazi-occupied countries were transported to concentration camps. They were herded into badly ventilated railroad trucks where they were deprived of food, water, and sanitation. Many died before they reached their final destinations (Mikaberidze 2013: 258). And when they eventually emerged, sick and exhausted, from the cattle trucks into places like Auschwitz, they realised that meticulous plans had been put in place to enact their fate. While death might come somewhat randomly from malnutrition, disease, freezing temperatures, or violence, Auschwitz functioned according to design. For example, in 1940 it was a former Polish Army barracks, converted under the leadership of Commandant Rudolf Höss and on the orders of Heinrich Himmler, into a camp to hold around Polish political prisoners. Over the next few years it developed into a network of sites designed to process tens of thousands of prisoners, utilizing some as workers for the German war effort in the East against Russia, and others to be mur- 
dered en masse, ${ }^{9}$ with their remains incinerated in crematoria in the dedicated extermination camp of Birkenau. As one commentator notes of Birkenau,

The Nazis had built suffering into the very plans. In a concentration camp in Germany this was the total space 3 inmates had to live in. Here at Auschwitz's new camp the original plan was to cram 9 prisoners into the same space. Five hundred and fifty in every barrack. But when the final calculations were made it was clear that even cramming the new prisoners together so tightly wasn't enough for the needs of the Nazis. So [newly appointed Auschwitz construction chief, Karl Bischoff] decided to force even more prisoners into each barrack. The documents reveal that he made a handwritten change - the figure 550 for each barrack was crossed out and replaced with 744 . The SS were designing barracks not so much to house people as to destroy them (Rees and Tatge 2005: Part two).

In all probability, Vladek and Anja survived because they were fortunate not to be transported to Auschwitz until March $1944 .{ }^{\text {IO }}$

In both the regime of quotidian camp life and overall planning of the Nazi Final Solution there is, therefore a sense of function that is similar in effect to Dante's mapping of Hell. A pertinent example of this is at Auschwitz, wherein Commandant Rudolf Höss had ordered a sign to be hung over its gate saying "Arbeit Macht Frei" (work will make you free). In apparent contrast, in Inferno Canto III at the gates of Hell are the words "All hope abandon, ye who enter in." ${ }^{\prime \prime}$ The Auschwitz sign ostensibly represents hope whereas in the Inferno the words infer absence of hope. Given the nature of Auschwitz, however, this was a cruel deception and a sign of false hope (Reiter 2004: 207). In Inferno the gate represents a turning point beyond which the old life or personality is forgotten. As survivors like Primo Levi and Vladek Spiegelman know, that was also the intention of the regime at Auschwitz - a process of dehumanisation to remove any hope of escape.

9. While the overall plans for the Final Solution were finalized, the methodology of mass murder was arrived at through trial and error. In Auschwitz, the Nazis began by shooting Russian prisoners. They then experimented with carbon monoxide poisoning. Finally, after successfully murdering a group of Russian prisoners with Zyklon B gas in August 194I, that became the preferred mode of mass killing.

IO. Auschwitz's gas chambers operated at full capacity in Spring and early Summer of 1944 due to the influx of hundreds of thousands of Hungarian Jews during that period of time. However, two main factors ensured that the extermination process would slow down afterwards. By mid-late Summer 1944, Germany suffered serious military setbacks. The Allies had landed in France and were advancing north and west; and the Russian Army was making advances in the West. Due to these military setbacks, as well as a shortage of labour for the war effort, Himmler ordered Auschwitz prisoners to be relocated to other camps. Gassings ended in November of that year as the Nazis began removing evidence of the true nature of the camp. Vladek and Anja were not part of this Hungarian influx and so were not included in the mass killings that took place during this time. Primo Levi, a former Italian partisan, also attributes his survival to being incarcerated late in the war. See preface to his book Survival in Auschwitz (NY, Collier: 196I).

II. The Gates of Hell is depicted in Auguste Rodin's sculpture, "The Gates of Hell”, I880-I9I7. 
Dante's vision of Hell and the Holocaust are also connected thematically: Judith Kelly remarks, for example, that in Levi's memoir "the infernal allusions are apparent from the very moment of the prisoners' arrival at Auschwitz. The orders barked out by the Germans as the prisoners are forced to disembark from the wagons remind one of Cerberus, the guardian of the third circle of Dante's Inferno, and the monstrous canine guard of Virgil's Hades. The guard who escorts the prisoners to the gates of Auschwitz puts Levi in mind of Charon, the ferryman, who takes Dante and Virgil across the River Acheron" (Kelly 2000: 65). A similar scene is evoked in Maus, wherein Art depicts his father and mother arriving through the gates of Auschwitz in the back of a truck, whereupon baton-wielding SS guards and a ferocious dog descend upon the vehicle. In a text box which partially obscures the "Arbeit Macht Frei" sign, Vladek contradicts it, saying: "We knew that from here we will not come out anymore" (Spiegelman 1986: Ch. 6).

When Dante enters the first circle of Upper Hell, he instantly finds himself in a "sorrowful abyss", a dark, cold and starless place: in this "blind world", he immediately hears the "infinite lamentations" of the huge, sprawling "crowds" of "infants and of women and of men" (Canto IV). These crowds, Virgil tells Dante, have "committed no sin" (they represent the un-Baptised or those who lived before Christian times), and are there for these "deficiencies" only (Canto IV), are particularly poignant in their similarity to the wailings of the crowds that Vladek first encounters when he first arrives in Auschwitz (SpiegeIman 1991: Ch. I). Of course, as Martin Walser has indicated, Auschwitz was not Hell and the Jews were not sinners. However, the notion that a real place existed where people from many cultures, connected only by their religion, were subjected to eternal punishment, suggests that Dante's Inferno provided a kind of lingua franca for those trying to depict Auschwitz, and their audiences.

Moreover, in Inferno, Dante gradually travels down through each of the Nine Circles of Hell (and the three individual rings in the Seventh Circle, the Nine Chasms of the Eighth Valley, and the four zones of Cocytus, the Ninth Circle), which have increasingly fiercer punishments for the gravity of the sins that souls have committed. On this journey it is revealed that sinners face punishments which correlate with the sins they committed when alive, and again, it is possible Spiegelman, in exploring his mother's suicide, may have taken particular inspiration from Dante's haunting "forest of suicides" (Canto XIII). In Inferno, when Dante and Virgil reach this second ring of the Seventh Valley of Hell, they find themselves in a dark, ominous, path-less forest, comprised of "knotted and twisted" branches, poisonous thorns and filthy muck (Canto XIII). Dante hears "cries coming from every direction" but cannot see anyone, yet soon realizes that the agonized voices are coming from tree stumps; on meeting the soul of Pier delle Vigne (a former advisor 
to Emperor Frederick II who killed himself before his scheduled execution), Dante learns that it is the fate of those who have committed suicide to have their souls grown into knotted trees, which are fed on by harpies who "inflict pain" - their fate is to be forever to searching for their bodies, and yet never be allowed to inhabit them again (Canto XIII).

As depicted in "Prisoner on the Hell Planet: A Case History", a comic book within a comic book in Maus, Anja Spiegelman - Art's mother and Vladek's wife - committed suicide in I968. In this story, Art discusses the possibility that he was responsible for his mother's suicide. He had been admitted to Binghamton State Mental Hospital and part of the terms of his release was that he stayed with his parents. However, in "Prisoner on the Hell Planet" he explains how he has little, if any connection with his parents, and how he coldly dismissed an attempt by his mother to elicit some affection from him. In fact, Anja had previously suffered from depression and it is likely that the death of her brother was the main cause of her suicide. Vladek explains, for example, "When Herman died from a hit-and-run driver in 1964, Anja started then also to die a little" (Spiegelman I99ı: Ch. 4). Nevertheless, Art's guilty feelings are demonstrated as he depicts himself in "Prisoner on the Hell Planet" in a prison uniform and later incarcerated in a cellblock with a layered structure reminiscent of the levels of Dante's Inferno. Anja's suicide, together with the guilt Art felt being her only surviving son because of Tosha's poisoning of Richieu, left Art in his own private hell. In this story within a story, connections are made across time and space. Artie's striped prison uniform in the mental hospital is similar to his father's Auschwitz prison uniform; Art depicts his face as contorted and twisted, much like Dante's twisted tree stumps; and much like in Dante's forest, where "cries come from every direction", Art also depicts cries and howling in his work - cries of "ANNA ANNA ANNA" in one picture, as well as "MENOPAUSAL DEPRESSION, HITLER DID IT!, MOMMY and BITCH" in another.

In addition to the ways in which Spiegelman borrows from the symbolism of Dante, the artwork in Maus is similar in style to some of the wood engravings that depict Dante's Inferno. For instance, the dark wood of suicides in the Seventh Circle is portrayed in Gustave Dorés I86I wood engraving "The Forest of Suicides". Of some of his early sketches, Art reflected that he had "a certain expertise at making this thing [his art] that looks like wood engravings" (Spiegelman 20II: I43) and Maus' extant artwork is a simplified version of that style. Furthermore, Art has expressed his admiration for what he refers to as Dorés "comic book" roots (Mullaney 2007: 27) and he reprinted some of the artist's public domain works in Raw, the comics anthology edited by Art and Françoise Mouly. A final indicative comparison between Art's illustrations and previous artistic depictions of Inferno, is English poet and painter William 
Blake, who illustrated this level of Hell in his "The Wood of the Self-Murderers: The Harpies and the Suicides" a pencil, ink and watercolour on paper (I824 to 1827 ). Although Art's technique is postmodern rather than romantic, his monochromatic style is reminiscent of Blake's interpretations of the Inferno.

There are many other examples of artistic similarities between Maus and Inferno which suggest Spiegelman had images of Dante's physical scenes of Hell in mind when depicting Vladek's accounts of Auschwitz. For example, when Virgil and Dante enter the Second Circle of Hell, they encounter Minos (who in Virgil's own work is the Judge of the Dead), who "scowling and terrible", examines "the faults of new arrivals" and judges them accordingly, sending "each to his place" (Canto V). Minos' function is to sort out the sinners into which place in Hell they are suited to and he "whips his tail around himself as many/ Times as the circles the sinner must go down" as he metes out judgement (Canto V). This bears striking similarities to the scowling, fang-baring cat that Spiegelman depicts as a Nazi guard, overseeing the separation of men and women on arrival at Auschwitz (as do the later drawings of the guards overseeing the "selektions" of prisoners for life or death, which continued throughout Vladek's time in the camp (Spiegelman 1991: Ch. I-2).

Moreover, another striking similarity between Maus and Inferno is that just like some of the demons in Inferno, Vladek also demonstrates that some of the Nazi officials and guards that he encountered could be bribed or persuaded to cooperate in some circumstances - but never trusted. For example, when Auschwitz was abandoned and Vladek and other prisoners were forced to march to Gross-Rosen concentration camp in Germany, some prisoners bribed Nazi guards to help them escape. However, when the time came, the guards shot them down (Spiegelman I991: Ch. 3). Similarly, in Cantos XXI and XXII of Dante's Inferno, when passing by the Fifth Valley of Malebolge by the burning river of boiling tar, Virgil appeals to a group of demons to secure safe passage to the next stage of their journey. Their leader, a demon called Malacoda, agrees to secure them safe passage, and commands his fellow devils not to harm them, but after helping them initially, the demons come for them "with wings spread / Not far away, and set on catching us" (Canto XXIII). It is only because of Virgil's quick-thinking and bravery that they survive this betrayal.

Perhaps most disturbingly, there are recurring images of burning in both works and in visualizing some of the most horrific suffering of Auschwitz, Spiegelman seems to borrow from some of Dante's incandescent, flaming imagery. For example, in one of the most artistically detailed sections of Maus, Vladek describes Auschwitz's methodology and machinery of extermination, including its ovens. Vladek tells how, near the end of his time in the camp, the Nazis burned alive many of the Hungarian Jews (Spiegelman I99I: Ch. 2). Spiegelman's graphic depiction of these horrific deaths evokes the haunting 
scene in Inferno, where "many droves of naked souls" were trapped on great burning sands where "dilated flakes of fire" rained down and caught alight, doubling the torment of the souls (Canto XIV). Furthermore, the fate of the Hungarian Jews is also markedly similar to the torments Dante witnesses in Canto IX, wherein he observes a vast plain, every side of which is filled with "cries and with cruel torments", where souls are entrapped in burning tombs "made completely incandescent" (Canto IX). There are many further images in Inferno of the "burning sands" and "infernal gales" which bear striking similarities to Vladek's words and Art's images about the immolation of Jews in the camps.

Furthermore, some of Vladek's most haunting memories of Auschwitz and Dachau are depicted by Art Spiegelman in ways that bear striking similarities to tortures in Dante's Inferno. For instance, towards the end of Vladek's story, when he recounts the horrors of the camp at Dachau, he tells Artie how he fell sick with typhus. At one point he recalls the times when he needed to get to the toilet at night, and how horrific it was because "it was always full, the whole corridor, with the dead people piled there": and that "you had to go on their heads, and this was terrible, because it was so slippery, the skin, you thought you were falling, and this was every night": the accompanying illustration Art provides is of Vladek's boots walking on the heads of dead mice (Spiegelman 199r: Ch. 4). This is comparable to Dante's depictions of the moment they enter "the sad pit" of Cocytus, the Ninth Circle of Hell. As they step over a frozen, opaque lake, Dante unwittingly scrambles over heads beneath him, and hears someone say: "Take care how you go by; Walk so as not to trample on the heads / Of brothers who are wretched and exhausted." On looking down, Dante then beholds "a thousand faces there", all of them "shadows tortured in the ice" (Canto XXXIII). Much like the links between the Forrest of Suicides and Art's "Prisoner of Hell Planet" imagery then, the connections between Dante's imagining of the horror of these frozen heads, and Art's depiction of Vladek's real experience, seem compelling.

Finally, both Spiegelman and Dante chose to end their stories in markedly similar ways. Dante's journey ends when he escapes Hell and looks up "to rebehold the stars". This is similar to the scene in Maus when Vladek, on the cusp of freedom, arrives by train at a German village near the Swiss border, whereupon he declares, "I saw, it's not everywhere, my hell. It's still LIFE things going on" (Spiegelman I99I: Ch. 4). Both have come through an ordeal and both still have challenges to come, but, for the moment, they have emerged triumphant from the "pit", having escaped death with newfound knowledge. Dante has observed the fate of the sinners in Hell and seems poised to embark on the right spiritual path, whereas Vladek's knowledge can best be understood with reference to the flashback scene in the prologue 
to Maus I: A Survivor's Tale: My Father Bleeds History. It is Rego Park New York in 1958 and a young Artie complains to his father that when he fell and hurt himself, his friends left him instead of helping. Vladek replies: "Friends? Your friends? If you lock them together in a room with no food for a week ... THEN you could see what it is, friends!" Like Dante, he has learned about human weakness, and humanity's capacity for cruelty and violence, and about the thin veneer of morality and law that protects the weak from the wicked.

In conclusion and summation, it remains the case that, to the best of our knowledge, Art Spiegelman has not mentioned Dante as an influence; furthermore, few critics have made the comparison, and those that have done so refer to it only in passing. ${ }^{\mathrm{I} 2}$ As we have explained, however, Dante's influence extends across time and cultures. Dante, and thereafter the artists who transformed his words into remarkable works of art, created the infernal imagery to which modern-day writers and artists often turn when making reference to the "underworld" - images that have reoccurred frequently and vividly over seven centuries; and when something as utterly horrific as the Holocaust came to light, it was then no surprise that survivors such as Primo Levi would utilize Dante's Inferno as an analytical tool to make sense of his experiences, and to draw upon a common well of imagery that could be used to describe his experiences to those who were not there. Spiegelman read Levi's biography and was an admirer of Gustave Doré, who is renowned for his depictions of the Inferno. We suggested four main points of comparison, not just to note the similarities between Dante's creation and Spiegelman's, but because we contend that those similarities are important in helping us understand events that are almost beyond description. This is especially important in an era in which Holocaust denial is becoming increasingly prevalent, and also more openly expressed. At the same time, if, as almost all evidence suggests, Maus has led to better understanding of the Holocaust and therefore to more empathy for the experiences of its victims, perhaps the "better angels" of our nature (Pinker 20II) will prevail and the particular circumstances which led to the Holocaust might, in future, be less likely to reoccur.

I2. See, for example, Brown 1993; Tabachnick 1993; Bosmajian I998; and Tabachnick 2004. 


\section{BIBLIOGRAPHY}

Adorno, TW., 1983, "Cultural Criticism and Society", in Prisms, Cambridge, MA: MIT, I7-34.

Bosmajian, H., I998, “The Orphaned Voice in Art Spiegelman's Maus I \& II”, Literature and Psychology, 44, I-2, pp. I-22.

Brown, M., I993, "Of 'Maus' and Men: Problems of Asserting Identity in a PostHolocaust Age", Studies in American Jewish Literature, I2, pp. I34-I40.

Budick, EM., 20or, "Forced Confessions: The Case of Art Spiegelman's Maus", Prooftexts, 2I, 3, pp. 379-98.

Doherty, T., 1996, "Art Spiegelman's Maus: Graphic Art and the Holocaust”, American Literature, 68, I, pp. 69-84.

Elmwood, VA., 2004, “'Happy, Happy, Ever After': The Transformation of Trauma between the Generations in Art Spiegelman's Maus: A Survivor's Tale", Biography, 27, 4, pp. 69I-720.

Feinstein, W., 2003, The Civilization of the Holocaust in Italy: Poets, Artists, Saints, Anti-semites, Madison N.J., Fairleigh Dickinson.

Harmsen, M., 20Io, "The Art of Maus: Self-Representation and Confession in the Graphic Novel”, Frame, 23, I, pp. 70-87.

Hastings, M., 20II, Inferno: The World at War, 1939-1945, London, HarperPress.

Higgins, DH., Introduction, in Alighieri D., The Divine Comedy, Oxford University Press, 2008.

Kelly, J., 2000, Primo Levi: Recording and Reconstruction in the Testimonial Literature, Market Harborough, Troubador.

Langer, LL., I995, “Memory's Time: Chronology and Duration in Holocaust Testimonies" in Langer, LL., (ed.), Admitting the Holocaust: Collected Essays, New York, Oxford Univeristy Press, pp. 13-24.

Levi, P. (1959), Survival in Auschwitz: the Nazi assaut on humanity [Se questo è un uomo], New York, Collier Books.

Lévi-Strauss, C., I962, Le totémisme aujourd'hui, Paris, Presses Universitaires de Paris.

Loman, A., 2006, "'Well Intended Liberal Slop': Allegories of Race in Spiegelman's 'Maus', Journal of American Studies, 40, 3, pp. 55I-7I.

Mikaberidze, A., (ed.), 2013, Atrocities, Massacres, and War Crimes: An Encyclopedia. Volume I, Santa Barbara, ABC CLIO.

McGlothlin, E., 2003, "No Time Like the Present: Narrative and Time in Art Spiegelman's Maus", Narrative, II, 2, pp. I77-98.

Mullaney, D., 2007, "Raw Magazine: An Interview with Art Spiegelman and Françoise Mouly" in Joseph Witek (ed.), Art Spiegelman: Conversations, Jackson, University Press of Mississippi, pp. 20-24.

Pertile, L., 20I3, Songs Beyond Mankind: Poetry and the Lager from Dante to Primo Levi, Binghamton, State University of New York, Center for Medieval and Renaissance Studies, (Bernardo Lectures Series, I8).

Pinker, S., 20II, The Better Angels of Our Nature: Why Violence Has Declined, New York, Viking.

Rees L., and Tatge C., (Dirs.), 2005, Auschwitz: The Nazis and 'The Final Solution', In six parts, UK, BBC.

Reiter, A., and Camiller, P., (trans), 2004, Narrating the Holocaust, London, Continuum. Spiegelman, A., 1986, Maus I: A Survivor's Tale: My Father Bleeds History, New York, Pantheon. 
Spiegelman, A., I99I, Maus II: A Survivor's Tale: And Here My Troubles Began, New York, Pantheon.

Spiegelman, A., 20II, Metamaus: a look inside a modern classic, Maus, London, Viking. Subiotto, AV., I99I, "Dante and the Holocaust: the cases of Primo Levi and Peter Weiss", New Comparison, II, pp. 70-89.

Tabachnick, SE., 1993, "Of Maus and memory: the structure of Art Spiegelman's graphic novel of the Holocaust", Word \& Image: A Journal of Verbal/Visual Enquiry, 9, 2, pp. 154-62.

Tabachnick, SE., 2004, "The Religious Meaning of Art Spiegelman's Maus", Shofar: An Interdisciplinary Journal of Jewish Studies, 22, 4, Pp. I-I3. 
